WojCIECH SKiba

INSTYTUT SOCJOLOGII

UNIWERSYTET WROCŁAWSKI

E-MAIL:WSKIBA@O2.PL

\title{
WSPARCIE DLA OSÓB NIEPEŁNOSPRAWNYCH W POWIATOWYCH STRATEGIACH ROZWIĄZYWANIA PROBLEMÓW SPOŁECZNYCH: EFEKTYWNA POMOC W REHABILITACJI, CZY PRZYPADKOWO DOBRANE DZIAŁANIA?
}

Artykuł prezentuje krótki przegląd wybranych powiatowych strategii rozwiązywania problemów społecznych (określane w dalszej części jako strategie) w części dotyczącej wsparcia dla osób niepełnosprawnych oraz stanowiących ich uszczegółowienie powiatowych programów działań na rzecz osób niepełnosprawnych (w dalszej części artykułu nazywane programami działań).

Podstawową kwestią rozważaną w artykule jest ocena, na ile wymienione powyżej dokumenty planistyczne umożliwiają przełamanie diagnozowanych, w publicznym dyskursie, dysfunkcji systemu instytucjonalnego wsparcia względem osób niepełnosprawnych, które przekładają się na stosunkowo niską efektywność prowadzonych działań [Gonciarz, Rudnicki 2014]1.

\section{Uwarunkowania tworzenia strategii i programów działań}

Zgodnie z ustawą o pomocy społecznej [Ustawa, 2004] strategie rozwiązywania problemów społecznych tworzone są obligatoryjnie przez jednostki samorządu terytorialnego, tak na poziomie gminnym, powiatowym i wojewódzkim. W odniesieniu do kreowania polityki lokalnej zorientowanej na osoby niepełnosprawne szczególne znaczenie mają strategie opraco-

1 Na tę kwestię zwracają uwagę m.in. [Gonciarz, Kubicki, Rudnicki, 2014]. 
wywane przez samorząd powiatowy, w nieco mniejszym stopniu i innym zakresie, także gminny i wojewódzki.

Z powyższego względu do przeglądu zostały wybrane strategie powiatowe. Artykuł 19 pkt 1 ustawy o pomocy społecznej mówi, że jednym z zadań własnych powiatu jest opracowanie strategii rozwiązywania problemów społecznych ze szczególnym uwzględnieniem m.in. wspierania osób niepełnosprawnych, w celu integracji ze społeczeństwem. W artykule 16.1 ustawodawca określa minimalne wymogi, które musi spełniać taka strategia, wskazując, iż powinna zawierać w szczególności:

1) diagnozę sytuacji społecznej;

2) prognozę zmian w zakresie objętym strategią;

3) określenie:

- a) celów strategicznych projektowanych zmian,

- b) kierunków niezbędnych działań,

- c) sposobu realizacji strategii oraz jej ram finansowych,

- d) wskaźników realizacji działań.

Z kolei ustawa o rehabilitacji [Ustawa, 1997] w art. 35 a nakazuje samorządom powiatowym opracowywanie i realizację, zgodnych z powiatową strategią dotyczącą rozwiązywania problemów społecznych, powiatowych programów działań na rzecz osób niepełnosprawnych w zakresie:

1) rehabilitacji społecznej;

2) rehabilitacji zawodowej i zatrudniania;

3) przestrzegania praw osób niepełnosprawnych.

Choć ustawodawca wyznaczył bardzo ogólne ramy sporządzania ww. opracowań, to szukając odpowiedzi jak powinna wyglądać strategia rozwiązywania problemów i powiatowy plan działań na rzecz niepełnosprawnych, w sukurs przychodzą nam zapisy ustawy o polityce rozwoju [Lipke, Hryniewiecka, 2008: 10-12], a także literatura naukowa i liczne poradniki określające sposoby tworzenia tego typu dokumentów [Podgórecki, 1996], metodologię przeprowadzania analizy SWOT, czy wyznaczania celów.

Bez względu na wewnętrzne bogactwo form sporządzania dokumentów o charakterze strategii, wspólnym mianownikiem planowania strategicznego, zgodnie z którą powinny być budowane oba wspomniane powyżej dokumenty, jest łączenie różnych obszarów prowadzenia polityk publicznych $\mathrm{w}$ ramach jednego zintegrowanego podejścia, celem bardziej efektywnego ich alokowania przy rozwiązywaniu konkretnych problemów. Odróżnia 
je to od podejścia sektorowego, które często ogranicza się do jednego obszaru tej polityki. Przykładowo, niski poziom aktywności zawodowej osób niepełnosprawnych powinien być rozpatrywany nie tylko w kontekście działań na rynku pracy, ale także w obszarze edukacji, pomocy społecznej, ochrony zdrowia, w tym funkcjonowania tzw. wczesnej rehabilitacji, czy zabezpieczenia społecznego [Gonciarz, Rudnicki 2014]. Elastyczność w łączeniu zasobów i definiowaniu celów działań to immanentne cechy tworzenia i realizacji strategii, tak jak i ich orientacja na efektywność. Tego ostatniego określenia ustawodawca nie wprowadził do katalogu określonego w art. 16.1 ustawy o pomocy społecznej, jednakże zgodnie z art. 44.1 ustawy o finansach publicznych [Ustawa, 2009: 31] wydatki publiczne powinny być dokonywane w sposób celowy i oszczędny, tak aby uzyskiwać najlepsze efekty z danych nakładów, przy optymalnym doborze metod i środków służących osiągnięciu założonych celów. Jednakże z założenia elastyczne podejście strategiczne, „zderza się" z sektorowym, „sztywnym” podejście w rzeczonych ustawach. Aby być pewnym zgodności wydatków z przepisami danej ustawy, realizujący zadania urzędnicy, nie ryzykują i w strategiach planują takie właśnie tytuły wsparcia, jakie enumeratywnie wylicza dany akt prawny. W ustawie o rehabilitacji większość form wsparcia została określona w latach 1991-97, przy czym część z nich ma rodowód sięgający czasów PRL, jak turnusy rehabilitacyjne, będące wówczas swoistym odpowiednikiem wczasów z Funduszu Wczasów Pracowniczych (FWP) dla osób niepełnosprawnych, przede wszystkim zatrudnionych w spółdzielniach inwalidów. Na przykład w przypadku rehabilitacji społecznej, ustawa [1997] zakłada dwie podstawowe jej formy: turnusy rehabilitacyjne i warsztaty terapii zajęciowej oraz szczegółowo normuje te formy wsparcia, określając najbardziej drobiazgowe aspekty realizacyjne. Jednocześnie z badań ewaluacyjnych wynika, iż efektywność tych form wsparcia, w odniesieniu do założonych przez ustawodawcę celów jest wątpliwa [Analiza 2009]. Co zatem powinien zrobić samorząd powiatowy? Określić, na podstawie wnikliwej diagnozy własne cele i sposoby ich realizacji, czy realizować zapisane $\mathrm{z}$ ustawie o rehabilitacji, ale poniekąd sprzecznie z duchem ustawy o finansach publicznych. Niestety, kształt przepisów, po części ten dylemat unieważnia. Ustawę, choć nie w całej rozciągłości, to realizować trzeba. Potrzeba efektywnych działań i zgodnej ze sztuką realizacji strategii stoi zatem w sprzeczności z ustawowymi wymogami, w których ustawodawca $\mathrm{z}$ góry zapisał jakiego typu wsparcie i w jaki sposób udzielane jest optymalne. Jak samorządy poruszają się w pomiędzy Scyllą wymogów efektywnego działania a Charybdą nakazów ustawowych? Krótki przegląd 
wskaże, jak samorządy w praktyce godzą wymogi podejścia horyzontalnego i efektywnościowego, które implikuje strategia i orientacji na określone procedury, czego wymagają poszczególne ustawy.

Tworząc, a następnie realizując strategię, działania z zakresu polityki społecznej w obszarze niepełnosprawności powinny być określone przez, będące pochodną wizji stanu docelowego, cele, wyznaczone adekwatnie do zdiagnozowanych i zhierarchizowanych potrzeb oraz scharakteryzowane przez wskaźniki realizacji. Wizję, ku której powinny zmierzać działania samorządów, określa ustawą o pomocy, wskazując integrację osób niepełnosprawnych i ich rodzin ze społeczeństwem, jako kluczowe cele polityki państwa w tym obszarze. Aby zmaterializować ten postulat, samorządowcy powinni korzystać z posiadanej autonomii w zakresie wyboru metod działania. Obejmuje ona wybór pomiędzy fakultatywnymi tytułami ustawowymi, a także możliwość działania projektowego oraz zlecania zadań w np. opartych na art. 36 ustawy o rehabilitacji i ustawie o działalności pożytku publicznego i wolontariacie. Dzięki tym narzędziom samorząd ma bardzo dużą swobodę w ustalaniu celów operacyjnych i zadań, na podstawie których będzie realizował ustawowy zapis o integracji przez rehabilitację społeczną, zawodową i ochronę praw osób niepełnosprawnych. Jeśli, w świetle wiedzy płynącej ze zdiagnozowanych w strategii potrzeb lokalnej społeczności, tytuły wsparcia zakładane ustawą wydają się być nieadekwatne do osiągnięcia strategicznego celu, to nie powinny być wykonywane, albo ich realizacja powinno być istotnie ograniczona. Alokowanie w ich realizację znacznych zasobów, w sytuacji ich ograniczonej wysokości, oznaczałoby bowiem naruszenie normy z ustawy o finansach publicznych, w związku z nieefektywnym wydatkowaniem środków publicznych i poważny błąd w tworzeniu i realizacji strategii.

\section{Przegląd wybranych strategii i programów działań}

Do analizy wybranych zostało 16 powiatowych strategii rozwiązywania problemów społecznych (po jednej z terenu każdego województwa) oraz powiązane $\mathrm{z}$ nimi programy działań na rzecz osób niepełnosprawnych $\mathrm{z}$ danego powiatu. Na etapie wyboru strategii do analizy dokonano kategoryzacji powiatów, różnicując je pod względem liczby mieszkańców i położenia, przy czym za wskaźnik drugiego kryterium uznano odległość od ośrodków wielkomiejskich, za które przyjęto miasta wojewódzkie. Jednocześnie należy zastrzec, że powyższy dobór nie miał na celu uzyskania reprezentatywnego doboru jednostek do badań, a jedynie zróżnicowanie pod 
względem wymienionych zmiennych. Stąd też z niniejszego przeglądu nie będą wyciągane wnioski odnoszące się do całej zbiorowości powiatów. Jej celem jest ukazanie istnienia, bądź nie, sygnalizowanych powyżej dysfunkcji realizacji określonych zadań publicznych oraz określenie mechanizmów go powodujących, bez dokładnego rozstrzygania co do ich powszechności. $\mathrm{W}$ efekcie do analizy wybrano wymienione w tabeli 1 powiaty.

Tabela 1. Wykaz powiatów objętych przeglądem strategii i programów powiatowych

\begin{tabular}{|l|l|l|}
\hline l.p. & Województwo & powiat (ziemski/ grodzki) \\
\hline 1 & Dolnośląskie & bolesławiecki (ziemski) \\
\hline 2 & Kujawsko- pomorskie & Miasto Grudziądz (grodzki) \\
\hline 3 & Lubelskie & puławski (ziemski) \\
\hline 4 & Lubuskie & żarski (ziemski) \\
\hline 5 & Łódzkie & radomszczański (ziemski) \\
\hline 6 & Małopolskie & bocheński (ziemski) \\
\hline 7 & Mazowieckie & Miasto Stołeczne Warszawa \\
\hline 8 & Opolskie & oleśnieński (ziemski) \\
\hline 9 & Podkarpackie & krośnieński (ziemski) \\
\hline 10 & Podlaskie & hajnowski (ziemski) \\
\hline 11 & Pomorskie & słupski (ziemski) \\
\hline 12 & Świętokrzyskie & jędrzejowski (ziemski) \\
\hline 13 & Śląskie & kłobucki (ziemski) \\
\hline 14 & Warmińsko-mazurskie & braniewski (ziemski) \\
\hline 15 & Wielkopolskie & poznański (ziemski) \\
\hline 16 & Zachodniopomorskie & policki (ziemski) \\
\hline
\end{tabular}

\section{Poziom zintegrowania zapisów strategii i powiatowego programu działań w obszarze działań dedykowanych osobom niepełnosprawnym}

Program działań powinien stanowić logiczne uzupełnienie strategii i być narzędziem realizacji określonych w niej celów. Jako wskaźnik przyjęto więc zgodność celów wskazanych $\mathrm{w}$ powiatowych programach działań $\mathrm{z}$ celami określonymi w strategii. Abstrahowano od powiązań tych dokumentów z innymi aktami normującymi zasady prowadzenia polityki względem osób nie- 
pełnosprawnych, jak Konwencja ONZ o Prawach Osób Niepełnosprawnych, programy wojewódzkie, Narodowa Strategia Rozwoju i inne.

W wyniku analizy wyróżnić możemy powiaty, w których stopień integracji obu dokumentów jest wysoki, a zadania zapisane w programie stanowią rozwinięcie celów określonych w strategii. W powiecie krośnieńskim klarownie zintegrowano oba dokumenty, określając w strategii, iż plan działań stawowi jego integralną część. W zasadzie pełna zgodność pomiędzy rzeczonymi dokumentami zachodzi w przypadku powiatów: hajnowskiego, poznańskiego ziemskiego, żarskiego oraz Warszawy. W stolicy program działań stanowi załącznik do strategii rozwiązywania problemów, zgodne są również okresy obowiązywania obu dokumentów. Pewne elementy sygnalizowane $\mathrm{w}$ strategii rozwijane były następne $\mathrm{w}$ stanowiącym załącznik programie. W przypadku powiatu kłobuckiego i radomszczańskiego na poziomie strategii dokonano powiązania działań wobec osób niepełnosprawnych i starych, słusznie wskazując, iż proces starzenia się nierozerwalnie wiąże się także z ubytkiem sprawności, jednakże na poziomie powiatowego planu działań ten związek zanika [Powiatowy... dla powiatu kłobuckiego; Powiatowy... dla powiatu radomszczańskiego].

Kolejną kategorię stanowią powiaty $\mathrm{w}$ których widoczne są pewne związki pomiędzy dokumentami, jednakże zadania określone w programie są w pewnym stopniu autonomiczne wobec zapisów strategii; przykładem jest tu powiat braniewski, w którym strategia wylicza większą liczbę celów niż powiatowy program działań. W efekcie, cześć celów strategii nie została ujęta w programie. Podobny problem dotyczy strategii powiatu bocheńskiego na lata 2009-2013 i programu działań na lata 2012-2014. W tym przypadku okres obowiązywania programu nachodzi na dwa okresy opracowywania strategii, co staje się źródłem dodatkowych rozbieżności pomiędzy celami określonymi w obu dokumentach. Podobnie jest w powiecie oleśnieńskim, gdzie strategia zawiera opis zasobów, dokonany częściowo na podstawie badań własnych oraz elementy diagnozy, za podstawę której posłużyły badania opinii niepełnosprawnych, z których wynikały potrzeby nie do końca zgodne z przyjętym celem (tworzenie całodziennych ośrodków zamkniętych vel integracja społeczna).

Ostatnia kategoria, to te powiaty, w których brak istotnych związków pomiędzy dokumentami strategicznymi. Do tej grupy zaliczyć można powiat bolesławiecki, gdzie strategia wymienia jedynie niepełnosprawność jako jeden z problemów, który wymaga interwencji; nie definiuje jednak strategicznych celów, które mogłyby być przeniesione do programu działań. 
Różne czasookresy obowiązywania rzeczonych dokumentów powodują oczywiste problemy z integracją dokumentów strategicznych. Na przykład w powiecie grudziądzkim strategia obowiązuje w latach 2014-20, a program w latach 2004-15, podobny mankament dotyczył powiatu polickiego. $\mathrm{W}$ efekcie dla celów $\mathrm{z}$ nowej strategii nie ma operacyjnego narzędzia realizacyjnego, ponieważ program zawiera stare cele. Brak troski o „zgranie” obu dokumentów interpretować można za wskaźnik fasadowości tych aktów, w myśl zasady: strategia, strategią, a realizujemy i tak zadania zapisane w ustawach: o rehabilitacji, o pomocy społecznej, czy o promocji zatrudnienia i instytucjach rynku pracy, bowiem w strategiach i tak za różnie zdefiniowanymi celami kryją się te same tytuły ustawowe. Z kolei w powiecie puławskim strategia zawiera diagnozę, z której wyprowadzone są cele szczegółowe i strategiczne, a powiatowy program w ogóle nie nawiązuje do tego dokumentu. Brak jest w nim operacjonalizacji celów, nie są tam one nawet przytoczone, a na sam program składają się głównie opisy różnych działań o charakterze projektowym, bez wskazania, jakie cele ze strategii mają one realizować.

Prosta z pozoru czynność, jaką jest nakazana ustawowo integracja obu dokumentów planistycznych w znacznej części samorządów wywołuje duże problemy. Wydaje się, że ich źródłem może być prymat myślenie budżetowego i sektorowego nad strategicznym. Z punktu widzenia zapewnienia najlepszej integracji obu dokumentów najwłaściwszy sposób postępowania przyjęto $\mathrm{w}$ dysponującej największymi zasobami i potencjałem Warszawie, czyniąc z programu działań na rzecz osób niepełnosprawnych załącznik do strategii rozwiązywania problemów społecznych, co zagwarantowała pełną zgodność i integralność obu opracowań.

\section{Kompletność diagnozy}

Według A. Podgóreckiego pełna diagnoza społeczna powinna obejmować następujące elementy: 1. Opis, oparty na danych empirycznych; 2. Ocenę - porównanie stanu rzeczy zastanych ze stanem rzeczy pożądanych; 3. Konkluzje - stwierdzenie, czy jakieś działanie jest potrzebne i należy go realizować czy też nie; 4. Tłumaczenie, obejmujące wyjaśnienie w różnych aspektach; 5. Postulowanie - zobrazowanie stanów rzeczy, które mają być realizowane lub wyeliminowanie oraz 6. Stawianie hipotez czyli związków między założonym działaniem, a przyczyną tego działania [Podgórecki, 1996]. W omawianych strategiach odnoszono się natomiast do przytoczonych wymogów ustawowych, które w pewnej części odpowia- 
dają tak rozumianej diagnozie. Stwierdzić należy, że z pewnością uwzględniają one opis, ocenę, konkluzję oraz, w formie prognozy, postulowanie stanu docelowego.

$\mathrm{Na}$ etapie opisu istotne $\mathrm{z}$ tego punktu widzenia jest, czy sporządzona zostanie dokładna charakterystyka populacji osób niepełnosprawnych z uwzględnieniem w niej różnych rodzajów i stopni niepełnosprawności, zasobów społecznych, materialnych, organizacyjnych, prawnych i innych które mogą w istotny sposób wpływać na projektowane działania, a następnie czy na tej postawie dokonano diagnozy ukierunkowanej głównym celem polityki państwa, a dążeniem do osiągnięcia integracji osób niepełnosprawnych i ich rodzin $\mathrm{z}$ resztą społeczeństwa.

$\mathrm{W}$ analizowanych dokumentach, opis i diagnoza były budowane przede wszystkim na formalnoprawnym szkielecie obowiązujących form wsparcia, określanych przede wszystkim przez ustawę o rehabilitacji, w mniejszym stopniu przez ustawę o pomocy społecznej i ustawę o promocji zatrudnienia i instytucjach rynku pracy. Zamieszkujące dany powiat społeczności osób niepełnosprawnych były więc $\mathrm{w}$ znacznej mierze rekonstruowane przez „sita” tych ustaw, poprzez charakteryzowanie ich jako korzystających z danej formy wsparcia, czy podpadających pod dany tytuł ustawowy. Podawano więc powszechnie takie dane jak: liczba niepełnosprawnych korzystających z poszczególnych tytułów wsparcia określonych w ustawie o pomocy społecznej, rehabilitacji, czy promocji zatrudnienia. Poza Warszawą brak było poważniejszych prób wyjścia poza ten scenariusz sporządzania diagnozy oparte na danych urzędowych, które mówiły przede wszystkim na co wydawane są publiczne pieniądze, a nie jakie potrzeby mają niepełnosprawni.

Będący podstawą dla dobrej diagnozy opis populacji praktycznie w żadnym $\mathrm{z}$ analizowanych jednostek samorządu terytorialnego nie został sporządzony w zadowalający sposób. Pod względem demograficznym populację charakteryzowano bardzo ogólnie, najczęściej określano liczbę osób niepełnosprawnych zamieszkujących dany powiat opierając się na danych historycznych, bez dokładniejszej kategoryzacji (np. powiaty bolesławiecki, krośnieński), często posługując się w tym celu danymi ze spisu powszechnego.

Tylko w części powiatów opisywano populację osób niepełnosprawnych ze względu na rodzaj niepełnosprawności. Czyniono to z reguły wykorzystując dane na temat bieżących orzeczeń z powiatowych zespół do spraw orzekania o stopniu niepełnosprawności. Przeważnie brak było jakichkolwiek odniesień do poszczególnych rodzajów niepełnosprawności, pojawiały się jedynie dane odnoszące się do struktury osób niepełnosprawnych na 
podstawie nowych orzeczeń, zwykle z roku poprzedzającego rok tworzenia strategii (powiaty braniewski, hajnowski, czy puławski). Dla przykładu, w strategii słupskiej, obok innych danych urzędowych, zaprezentowano strukturę wydanych orzeczeń ze względu na rodzaj orzeczonej niepełnosprawności, co stanowi nieco lepszy punkt wyjścia do analizy potrzeb i barier oraz wyznaczania wynikających $z$ nich celów działań [powiat słupsk 2015]. Z kolei strategia dla powiatu bocheńskiego jako główne źródło danych do diagnozy traktuje informacje o strukturze wnioskujących do powiatowego zespołu orzekania o stopniu niepełnosprawności i wydanych orzeczeniach, a także dane historyczne na temat pomocy udzielanej ze środków PFRON. Zakres ten poszerza nieco program, m.in. o dane na temat organizacji pozarządowych działających w powiecie oraz dane spisowe.

Na przeciwległym krańcu znajdują się powiaty, w których na poziomie diagnozy nie dokonano zróżnicowania populacji osób niepełnosprawnych ze względu na rodzaj niepełnosprawności. Jedynymi kategoriami różnicującymi były dane na temat stopnia niepełnosprawności oraz pewne elementy struktury wiekowej (np. powiat krośnieński, czy bolesławiecki), często w tym względzie, zwłaszcza w strategiach powstałych przed publikacją wyników spisu powszechnego podawano dane odnoszące się do całego kraju, czy województwa, także na podstawie badań BAEL.

Częstym błędem popełnianym przez samorządy jest utożsamianie opisu $z$ diagnozą. Zwykle dane przytaczane są bez wyznaczenia kierunkującej ich zbieranie i analizę perspektywy, więc nie spełnia on wymogów stawianych diagnozie społecznej [Szatur-Jaworska, 2003]. Można powiedzieć, iż wśród analizowanych samorządów funkcjonuje ukryte założenie o braku potrzeby dokładnego różnicowania populacji osób niepełnosprawnych i nie dostrzega się znaczenia tego procesu dla powodzenia projektowanych działań w obszarze integracji i aktywizacji osoby niepełnosprawnej. Przykładowo, w programie działań dla powiatu poznańskiego ziemskiego brak zróżnicowania populacji ze względu na rodzaj niepełnosprawności. Dla przykładu, w stosunku do osób $\mathrm{z}$ upośledzeniem słuchu brak jest jakiegokolwiek opisu, a w przypadku osób niewidomych i upośledzonych umysłowo dokument wylicza tylko instytucje wsparcia, w żaden sposób nie indywidualizując planowanych działań w odniesieniu do tych, czy także innych kategorii osób niepełnosprawnych. Podobny brak zróżnicowania populacji osób niepełnosprawnych ze względu na rodzaj niepełnosprawności charakteryzuje pozostałe analizowane dokumenty. Rodzaj niepełnosprawności bywa wyspecyfikowany tylko i wyłącznie w kontekście dedykowanych tym niepeł- 
nosprawnościom form wsparcia, które wynikają z odrębnych przepisów, np. domów pomocy społecznej dla osób psychicznie chorych, warsztatów terapii zajęciowej, czy środowiskowych domów samopomocy oraz innych profilowanych placówek, w których uczestnictwo zarezerwowane jest dla osób z danym typem dysfunkcji. Dokładniejszy opis, w odniesieniu do korzystających $\mathrm{z}$ tych instytucji, nie wynika więc $\mathrm{z}$ diagnozowania potrzeb osób niepełnosprawnych, tylko $\mathrm{z}$ funkcjonujących rozwiązań systemowych. Wydaje się, że takie, powszechnie występujące podejście, ma istotne znaczenie dla jakości strategii i wpływa na możliwość realnego oddziaływania tych dokumentów na poprawę jakości wsparcia dla osób niepełnosprawnych.

Kolejna problemowa kwestia odnosząca się do diagnozy, to sprostanie ustawowemu wymogowi zawarcia w strategii prognozy przyszłego stanu. Prognoza powinna zawierać informacje o potrzebach, problemach i zasobach danej społeczności lokalnej, które wynikają z analizy danych opisujących stan społeczności lokalnej w ostatnich latach i uwzględniają tendencje zmian odnoszące się do szerszych całości: regionu, kraju, w okresie, w jakim będzie realizowana strategia [Podgórecki, 1996]. Element prognozy jest praktycznie pomijany w strategiach, które powstały przed nowelizacją ustawy o pomocy społecznej w 2011, wprowadzającej ten wymóg.

Następnym napotkanym problemem była niekoherentność danych pomiędzy powiatowymi strategiami i programami. Często dane użyte w diagnozie $\mathrm{w}$ jednym $\mathrm{z}$ dokumentów uzupełniają drugie i dopiero zapoznając się oboma dokumentami możliwe jest uzyskanie pełniejszego obrazu. Przyczyną tego stanu rzeczy mógł być, sygnalizowany już wcześniej, różny czasookres obowiązywania obu dokumentów w części powiatów.

W niektórych powiatach diagnozę częściowo opierano na przeprowadzonych badaniach ankietowych (np. powiaty puławski, oleśniański, kłobucki, radomszczański). Jednakże zawsze były to badania niereprezentatywne. Nie stosowano również kwotowego doboru próby. Podstawowym kryterium objęcia badaniem była dostępność respondenta (np. w powiecie puławskim i oleśniańskim badaniem objęto osoby niepełnosprawne objęte już instytucjonalną pomocą). W badaniach kładziono główny nacisk na kwestie, które z punktu projektowania optymalnego wsparcia nie mają większego znaczenia, np. identyfikowano znajomość poszczególnych instytucji powiatowych. Z kolei w powiecie kłobuckim ankietą obejmującą wszystkie obszary składające się na strategię rozwiązywania problemów objęto ogółem 59 osób. Na uwagę zasługuje badanie przeprowadzone w powiecie radomszczańskim, w którym ankietę skierowano do 198 osób mają- 
cych wpływ na prowadzenie polityki społecznej w powiecie i realizację zadań z zakresu polityki społecznej, traktując tę kategorię osób jako sędziów kompetentnych. Jednakże charakter pytań w dużej mierze zmniejszył potencjał diagnostyczny takiego badania.

Stosunkowo najpełniej diagnoza przeprowadzona została $\mathrm{w}$ strategii warszawskiej, gdzie cześć inwentaryzacyjno-diagnostyczna obejmowała prace rozciągnięte $\mathrm{w}$ długiej perspektywie czasowej, prowadzone przez szereg zespołów tematycznych, w tym zespół do spraw niepełnosprawności, a na poziomie opracowania strategii przedstawiono już wyłącznie diagnozę rozumianą jako ukierunkowany opis; sama inwentaryzacja zasobów znalazła się natomiast w programie. $\mathrm{Z}$ analiz wyprowadzono wniosek o konieczności projektowania wsparcia $\mathrm{w}$ sposób zindywidualizowany, zależny od specyficznych potrzeb i barier, jakich doświadcza osoba niepełnosprawna.

\section{Uspołecznienie procesu tworzenia strategii i programu działań, włączenie osób niepełnosprawnych w prace i zapewnienia im realnego wpływu na ich kształt}

Partycypacja społeczna, oprócz kwestii związanych z wdrażaniem demokracji uczestniczącej, stanowi także pragmatyczny postulat dzięki realizacji którego możliwe jest wypracowywanie bardziej efektywnych rozwiązań różnych kwestii społecznych [Chojnowska-Ochnik, 2010]. Idea uspołecznienia procesu tworzenia strategii rozwiązywania problemów społecznych nie znalazła posłuchu $\mathrm{w}$ analizowanych dokumentach i de facto została ograniczona do wymaganych konsultacji ze społecznymi radami do spraw osób niepełnosprawnych, obligatoryjnie funkcjonującymi w powiatach. Oprócz omawianych już badań opinii, które można potraktować jako formę konsultacji na poziomie diagnozy, konsultowaniu podlegały zwykle gotowe dokumenty, a nie założenia strategii czy programu. W omawianych dokumentach trudno doszukać się informacji o aktywnym włączeniu zamieszkujących dany powiat osób niepełnosprawnych i organizacji w całokształt prac; w części powiatów umożliwiano konsultacje przez tworzenie stron internetowych strategii. Wydaje się, że najdalej idące konsultacje społeczne miały miejsce w Warszawie. Przebiegały one wieloetapowo, przy wykorzystaniu istniejących instytucji konsultacyjno-doradczych (Forum Polityki Społecznej), w ich efekcie uwzględniono znaczną cześć zgłaszanych uwag. W zespołach tworzących strategię zasiadali przede wszystkim etatowi pracownicy starostw i ich jednostek organizacyjnych oraz innych 
instytucji publicznych, brak było często całkowicie przedstawicieli sektora organizacji pozarządowych i biznesu, od zaangażowania których zależy następnie realizacja znacznej części działań. W zespole do spraw opracowania strategii powiatu słupskiego (grodzkiego) uczestniczyło 35 osób, w tym tylko jeden przedstawicieli organizacji pozarządowej oraz jeden przedstawiciel ciała społecznego działającego przy starostwie (społeczna rada do spraw niepełnosprawnych), brak było przedstawicieli sektora gospodarczego.

\section{Adekwatność celów strategii i programów działań do zdiagnozowanych problemów osób niepełnosprawnych}

Odpowiedź na tak postawione pytanie w kontekście wcześniejszych spostrzeżeń wskazujących na istotne mankamenty procesu diagnozy problemów dotykających osoby niepełnosprawne, w szczególności brak odniesienia do specyficznych potrzeb poszczególnych kategorii osób niepełnosprawnych, nastręcza pewne trudności. Skoro diagnoza jest nieadekwatna, to adekwatność celów do tak sporządzonej diagnozy nie będzie wskaźnikiem dobrej jakości strategii i programu działań. Jednakże, nawet gdyby przyjąć sporządzane przez powiaty diagnozy za adekwatnie oceniające potrzeby osób niepełnosprawnych i bariery ich integracji, to odpowiedź na tak sformułowaną kwestię tylko po części byłaby twierdząca. Byłoby tak, np. w odniesieniu do zdiagnozowania istnienia barier (architektonicznych, komunikacyjnych, mentalnych) i formułowania $\mathrm{w}$ wyznaczanych celach postulatów ich usuwania. W tym aspekcie część problemów, $\mathrm{z}$ racji ich powszechności, można i należy uznać za wspólne, jak występowanie wspomnianych barier. Jednakże samo formułowanie postulatu ich usunięcia, nie gwarantuje osiągnięcia zakładanego efektu w odniesieniu do wszystkich kategorii osób niepełnosprawnych, głównie ze względu na wspomniany już problem braku odniesień do specyficznych, determinowanych przez rodzaj niepełnosprawności, potrzeb w tym względzie. Świadczy to bądź o ignorancji decydentów, bądź o rezygnacji z zarządzania tą kwestią i pośrednio całym procesem osiągania danego celu. Doświadczenia innych państw, a także polskie, płynące z realizacji projektów, w których wsparcie dostosowane jest stricte do potrzeb danej osoby, wskazują, że zindywidualizowane podejście uwzględniające wszystkie istotne aspekty sytuacji jednostki daje znacznie większą szansę powodzenia procesu integracyjnego [Rozmus, 2014]. Zapowiedź działania w taki właśnie sposób obecna jest tylko w strategii warszawskiej i stanowiącym jej cześć programie działań na rzecz niepełnosprawnych [politykaspoleczna, 2015]. 
Wskazane do realizacji w rzeczonych dokumentach cele wynikają zwykle $\mathrm{z}$ ustaw o rehabilitacji, pomocy społecznej i promocji zatrudnienia. Wyznaczone cele stanowią więc często powielenie tytułów ustawowych. W ten sposób analizowane dokumenty strategiczne stają się, podobnie jak wzmiankowane ustawy, dokumentami zorganizowanymi pionowo, a nie horyzontalnie. Problematyka niepełnosprawności zostaje w nich rozbita na kwestie przypisane do danych ustaw i często oddzielnie omawiana. Zaprzecza to idei tworzenia strategii jako programu horyzontalnego łączącego „różne urzędnicze światy”. Połączenie tych działań na jednej karcie strategii, to zbyt mało. Nie wynika z tego integracja działań w praktyce. Przykładowo, w programie działań dla powiatu Krosno aż 17 z 20 zadań stanowią cele przeniesione $\mathrm{z}$ ustawy o promocji zatrudnienia i ustawy o rehabilitacji, a pozostałe 3 mają charakter działań „miękkich”. Podobnie jest w większości pozostałych strategii. W niektórych przypadkach możemy mówić o adekwatnym doborze środków do celów np. powiecie hajnowskim, czy w Warszawie, w której założono przeprowadzenie programu operacyjnego „wsparcie osób niepełnosprawnych w społeczności lokalnej”, którego celem było dokładne zdiagnozowanie specyficznych potrzeb osób z różnymi niepełnosprawnościami i testowanie rozwiązań służących ich integracji, a następnie upowszechnianie tych optymalnych [umwarszawa, 2015].

Część samorządów zdaje sobie sprawę z ograniczonej efektywności narzędzi w stosunku do założonych dla nich celów, na podstawie których prowadzona jest rehabilitacja, jednak na poziomie strategicznym nie planuje żadnych działań, które mogłyby ten stan zmienić i np. zapewnić kompleksowość wsparcia i synergię działań. Przykładowo, ograniczony przepisami czas pobytu $\mathrm{w}$ warsztatach terapii zajęciowej, w świetle charakterystyki kierowanych do nich osób (przeważnie osoby ze znacznym i umiarkowanym stopniem niepełnosprawności intelektualnej) i celów, które mają osiągnąć dzięki realizacji programu pobytu, sprawia, że w świetle praktyki funkcjonowania WTZ, zakładane rezultaty są bardzo trudne do osiągnięcia. Pobyt w WTZ ulega więc najczęściej znacznemu przedłużeniu, ponad czas określony $\mathrm{w}$ przepisach. $\mathrm{W}$ efekcie prowadzone $\mathrm{w}$ każdym $\mathrm{z}$ analizowanych powiatów WTZ, co prawda realizują cel polegający na "rehabilitacji społecznej”, ale od lat nie osiągają celu określonego w ustawie. Nie spowodowało to jednak dotąd uelastycznienia przepisów dotyczących tej formy wsparcia, która pozwoliłaby efektywniej wykorzystać jej tracony potencjał. 


\section{Operacjonalizacja celów i zadań, wskaźniki realizacji}

W analizowanych strategiach i programach działań cele stosunkowo rzadko są charakteryzowane przez wskaźniki, jeśli już tak się działo są to z reguły wskaźniki produktu. W efekcie trudno ocenić wpływ realizowanych zadań na sytuację osób niepełnosprawnych w powiecie. Najczęściej także brak określenia ram czasowych realizacji poszczególnych wskaźników, a także podania wysokości poszczególnych wskaźników. Nie wiadomo więc, czy dany powiat zaktywizuje zawodowo, społecznie, czy wyśle na turnus rehabilitacyjny jedną osobę niepełnosprawną czy 1000 osób i w jaki sposób wpłynie to na realizację naczelnego celu polityki społecznej państwa w tym obszarze. Z pewnością świadczy to o prowadzeniu działań, które mają charakter integracyjny, a nie wyłączający. Ich piętą achillesową jest jednak epizodyczny charakter w odniesieniu do danej osoby niepełnosprawnej. Opierając się na tak przyjętych programach w zasadzie możliwe jest prowadzenie każdej polityki wobec osób niepełnosprawnych, nie precyzują więc one dostatecznie zamierzeń władz w tym zakresie i nie stanowią przez to dobrych dokumentów planistycznych. W powiecie oleśnieńskim cele zostały scharakteryzowane przez wskaźniki na poziomie strategii, natomiast $\mathrm{w}$ programie już nie. Z kolei np. w powiecie żarskim przypisano jedynie odpowiedzialnych za realizację poszczególnych celów, a termin realizacji określono w całym zakresie czasowym obowiązywania strategii.

Podobnie jak w innych wymiarach analizy, także w tym najlepiej prezentuje się strategia warszawska, a także policka. Cele są scharakteryzowane przez wskaźniki, określone w czasie, przypisane są do nich konkretne zasoby (finansowe, rzeczowe) na podstawie których będą one realizowane oraz wyznaczone podmioty odpowiedzialne za ten proces.

W przypadku niektórych powiatów, np. braniewskiego, zadania i działania dobrze charakteryzujące przyjęte cele szczegółowe, brak jest natomiast określenia jakichkolwiek ram czasowych realizacji poszczególnych zadań i zasobów, na podstawie których miałyby one zostać zrealizowane. O ile część $\mathrm{z}$ nich stanowi tytuły ustawowe, np. turnusy rehabilitacyjne, które mają ustalone prawnie procedury realizacji, o tyle inne wymagałyby szczegółowego dookreślenia na poziomie programu, tak aby uznać go za realistyczny.

Częstym problemem jest wyznaczanie nieadekwatnych wskaźników do wyznaczonych celów. Przykładowo, w strategii powiatu słupskiego jednym z celów jest zwiększenie dostępności osób niepełnosprawnych do zasobów rynku pracy, a przyjętym wskaźnikiem monitorującym realizację celu jest 
liczba projektów zrealizowanych na rzecz osób niepełnosprawnych. Na poziomie programu działań cel ten $\mathrm{w}$ jest określony przez różne zadania, dla których nie przyjęto żadnych wskaźników realizacji.

\section{Podsumowanie}

Przedstawione powyżej rozważania w zamyśle autora miały stanowić przede wszystkim przyczynek do dyskusji nad zmianami w zasadach i instrumentach polityki społecznej w obszarze rehabilitacji i integracji społecznej osób niepełnosprawnych. Obecnie obowiązujący model, przez dokładne określanie rodzajów zadań, które mogą być finansowane z danego strumienia środków publicznych i dokładne określanie procedur realizacyjnych często wyklucza elastyczność będącą warunkiem dobrej strategii, czy podejścia projektowego. Cechuje go silna koncentracja na procedurach, a efekty działań wydają się być drugorzędne. W efekcie powiatowe strategie i mające je dopełniać programy działań, $\mathrm{z}$ reguły nie mogą stanowić nowej jakości w kreowaniu rozwiązań służących realizacji celów polityki społecznej w obszarze integracji osób niepełnosprawnych. Trudno za ten fakt winić jedynie, a nawet przede wszystkim, samorządy. O ile na etapie tworzenia tych strategii i programów działań często nie ustrzegły się one błędów, które nieraz uniemożliwiają właściwe rozpoznanie i zdefiniowanie problemu, a w efekcie skuteczne działania, o tyle w zakresie doboru narzędzi do rozwiązywania tych problemów i tak mają one mocno związane ręce. Dzieje się tak, bo do logiki charakterystycznej dla myślenia strategicznego nie zostały dostosowane zapisy ustaw i aktów wykonawczych do nich wydanych. Dotyczy to zwłaszcza ustawy o rehabilitacji społecznej i zawodowej oraz zatrudnieniu osób niepełnosprawnych. Tworzony przez nią model rehabilitacji uznać należy za mocno archaiczny i przede wszystkim nieefektywny, czego dowodzą same wypowiedzi osób odpowiedzialnych za ten obszar [Gonciarz, Rudnicki, 2014].

\section{Bibliografia:}

Analiza działalności warsztatów terapii zajęciowej w 2008 r. (2009) Warszawa, PFRON. Anasz M., Mrugalska K., Wojtyńska J. (2012), Życie w integracji, PFRON, Warszawa. bochnia.starostwo.gov.pl/.../powiatowa_strategia (dostęp: 11.01.2015).

boleslawiec.pcpr.info/download/boleslawiec/strategia_2008.pdf (dostęp: 11.01.2015). 
bip.klobuck.pl/2928/powiatowy-program-dzialan-na-rzecz-osob-niepelnosprawnych. html (dostęp: 14.01.2015).

bip.malopolska.pl/spbochnia/Article/get/id,193783.htm, (dostęp: 14.01.2015).

bip.powiat.krosno.pl/?c=mdTresc-cmPokaz-535 (dostęp: 14.01.2015).

bip.powiatoleski.pl/490/powiatowy-program-dzialan-na-rzecz-osob-niepelnosprawnych -na-lata-2011-2020.html (dostęp: 14.01.2015).

bip.um-braniewo.iq.pl/download_attachment.php?f=attachment...pdf, (dostęp: 11.01.2015). bip.zary.pl/89/1686/Strategia_Rozwiazywania_Problemow_Spolecznych_na_terenie_ Gminy_Miejskiej_Zary_na_lata_2006-2013/,(dostęp: 11.01.2015).

Chojnowska-Ochnik N., Singer E. (red.), (2010), Metodologia wspierania rozwoju społecznego gminy przez partycypacje, Warszawa, MPiPS.

Giermanowska E. (2007), Młodzi niepetnosprawni o sobie: rodzina, edukacja, praca, Warszawa, ISP.

Gonciarz B., Kubicki P., Rudnicki S. (2014), System infrastruktualnego wsparcia osób niepetnosprawnych $w$ Polsce - diagnoza dysfunkcji, (w:) B. Gonciarz, S. Rudnicki, (red.), Polacy niepetnosprawni. Od kompleksowej diagnozy do nowego modelu polityki społecznej, Warszawa, AGH.

Gonciarz B., Ostrowska A., Pańków W. (2008), Integracja społeczna i aktywizacja zawodowa osób niepełnosprawnych zamieszkałych $w$ małych miasteczkach i na terenach wiejskich, Warszawa, IFiS PAN.

Gonciarz B., Rudnicki S. (red.), (2014), Polscy niepełnosprawni. Od kompleksowej diagnozy do nowego modelu polityki społecznej, Kraków, AGH.

Gorajewska D. (2005), Społeczeństwo równych szans. Tendencje i kierunki zmian, Warszawa, Integracja.

grudziadz.pl/uploads/files (dostęp: 14.01.2015).

Jaworski J. (2009), Praca dla osób niepetnosprawnych $w$ zwalczaniu ich wykluczenia społecznego, Warszawa, PBZ.

jedrzejow.pl/141-konsultacje-spo\%C5\%82eczne/310-powiatowa-strategia-rozwi\%C4\%85zywania-problem\%C3\%B3w-spo\%C5\%82ecznych-na-lata-2014-\%E2\%80\%93-2021. html (dostęp: 11.01.2015).

Kołaczek B. (2010), Polityka społeczna wobec osób niepełnosprawnych, Warszawa, IPiSS.

Lipke H., Hryniewiecka A. (2008), Raport. Analiza strategii rozwiązywania problemów społecznych, Warszawa, IRSS.

Marynowicz-Hetka E., Piekarski J. (1996), Wokół problemów działania społecznego, Warszawa, Wydawnictwo Interart.

mopr.grudziadz.pl/index.php/strategia (dostęp: 11.01.2015).

pcprbraniewo.pl/wpcontent/uploads/2012/11/powiatowy_program_dzialan_na_rzecz_ osob_niepelnosprawnych_2012-2020.pdf (dostęp: 14.01.2015).

pcpr.police.pl/attachments/article/79/ (dostęp: 11.01.2015).

pcpr.police.pl/strategie-i-programy/program-na-rzecz-osob-niepelnosprawnych-w-powiecie-polickim-w-latach-2004-2014.html (dostęp: 14.01.2015).

pcpr.powiat.poznan.pl/?c=315 (dostęp: 14.01.2015).

pcpr.powiatzarski.pl/Powiatowy_program_dzialan_na_rzecz_osob_niepelnosprawnych_15_20.doc (dostęp: 14.01.2015). 
Powiatowy Program Działań na rzecz Osób Niepełnosprawnych dla powiatu radomszczańskiego, http://www. pcpr.radomsko.pl/PON.pdf (dostęp: 14.01.2015).

pcpr.radomsko.pl/Strategia.pdf (dostęp: 11.01.2015).

Podgórecki A., (1996), Tok postępowania celowościowego, (w:) E. Marynowicz-Hetka, J. Piekarski (red.), Wokół problemów działania społecznego, Warszawa, Wydawnictwo Interart.

politykaspoleczna.um.warszawa.pl/aktualnosci/warszawski-program-dzialan-na-rzecz -osob-niepelnosprawnych (dostęp: 14.01.2015).

powiatboleslawiecki.pl/niepe $\%$ C5\% 82 nosprawno\%C5\%9B\%C4\%87/programy-realizowane-na-rzecz-os\%C3\%B3b-niepe\%C5\%82nosprawnych/powiatowy-programdzia\%C5\%82a\%C5\%84-na-rzecz-os\%C3\%B3b-niepe\%C5\%82nosprawnych-na-lata2011-\%E2\%80\%93-2015.html (dostęp: 14.01.2015).

powiat.hajnowka.pl/archiwum/2008/maj/PCPR-BIP/Strategia.pdf (dostęp: 11.01.2015).

powiat.krosno.pl/strategia-rozwizywania-problemow-spoecznych-w-powiecie-kronieskim-na-lata-2008-2015 (dostęp: 11.01.2015).

Powiatowy Program Działań na rzecz Osób Niepełnosprawnych dla powiatu kłobuckiego na lata 2012-18, http://bip.pcpr.klobuck.pl/30/powiatowy-program-dzialan-na -rzecz-osob-niepelnosprawnych-z-powiatu-klobuckiego-na-lata-2012-2018.html (dostęp: 01.01.2015)

powiat.slupsk.pl/plik,821,program-dzialan-na-rzecz-osob-niepelnosprawnych-w-powiecie-slupskim-na-lata-2013-2015.pdf (dostęp: 14.01.2015).

pulawy.powiat.pl\%2Fstrona\%2Findex.php\%2Fstrategia-rozwoju-powiatu-puawskiego-na -lata-2008-2015 (dostęp: 11.01.2015).

Rozmus P. (2014), Co hamuje, a co przyśpiesza aktywizująca i integrująca politykę społeczna. Źródła sukcesów i niepowodzeń instytucji wsparcia, (w:) B. Gonciarz, S. Rudnicki (red.), Polscy niepełnosprawni. Od kompleksowej diagnozy do nowego modelu polityki społecznej, Kraków, AGH.

Szatur- Jaworska B. (2003), Diagnozowanie w polityce społecznej, Warszawa, Uniwersytet Warszawski.

um.warszawa.pl/sites/default/files/Spoleczna_Strategia_WarszawyStrategia_Rozwiazywania_Problemow_Spolecznych_na_lata_2009-2020.pdf (dostęp: 11.01.2015).

Ustawa z dnia 12 marca 2004 r. o pomocy społecznej, tekst jednolity, (Dz. U. 2004, nr 64, poz. 593) http://isap.sejm.gov.pl/DetailsServlet?id=WDU20040640593, (dostęp: 31.01.2015).

Ustawa z dnia 27 sierpnia 1997 r. o rehabilitacji zawodowej i społecznej oraz zatrudnieniu osób niepełnosprawnych, tekst jednolity, (Dz. U. 1997, nr 123, poz. 776) http:// isap.sejm.gov.pl/DetailsServlet?id=WDU19971230776 (dostęp: 31.01.2015).

Ustawa z dnia 27 sierpnia 2009 r. o finansach publicznych, tekst jednolity, (Dz. U. 2009, nr 157, poz. 1240) http://isap.sejm.gov.pl/DetailsServlet?id=WDU20091571240 (dostęp: 31.01.2015).

Ustawa z dnia 24 kwietnia 2003 r. o działalności pożytku publicznego i wolontariacie, tekst jednolity, (Dz. U. 2003, nr 69, poz. 873) http://isap.sejm.gov.pl/DetailsServlet?id=WDU20030960873 (dostęp: 31.01.2015).

Ziemski S. (1973), Problemy dobrej diagnozy, Warszawa, WP. 
SUMMARY

Support for people with disabilities in the district strategies of solving social problems: effective aid in rehabilitation, or randomly-selected action?

The article presents an analysis of selected county social problem-solving strategies and county programs of activities for people with disabilities. The subject of the study was to assess the extent, based on these documents it is possible to carry out effective measures aimed at social integration of people with disabilities.

\section{Keywords:}

effective help, rehabilitation of disabled people, social inclusion, social policy, sociology, social problems 